\title{
Improving efficiency and environmental impact applying JIT logistics and transport consolidation in urban construction projects
}

\author{
Ruben Vrijhoef ${ }^{\mathrm{a}, \mathrm{b}}$ \\ ${ }^{a}$ Delft University of Technology, PO Box 5043, NL-2600 GA Delft, The Netherlands \\ ${ }^{b}$ Utrecht University of Applied Sciences, PO Box 182, NL-3500 AD Utrecht, The Netherlands
}

\begin{abstract}
The way in which construction logistics is organised has considerable impact on production flow, transportation efficiency, greenhouse gas emissions and congestion, particularly in urban areas such as city centres. In cities such as London and Amsterdam municipalities have issued new legislation and stricter conditions for vehicles to be able to access cities and city centres in particular. Considerate clients, public as well private, have started developing tender policies to encourage contractors to reduce the environmental impact of construction projects. This paper reports on an ongoing research project applying and assessing developments in the field of construction logistics in the Netherlands. The cases include contractors and third party logistics providers applying consolidation centres and dedicated software solutions to increase transportation efficiency. The case show various results of JIT logistics management applied to urban construction projects leading to higher transportation efficiencies, and reduced environmental impact and increased production efficiency on site. The data collections included to-site en on-site observations, measurement and interviews. The research has shown considerable reductions of vehicles to deliver goods and to transport workers to site. In addition the research has shown increased production flow and less waste such as inventory, waiting and unnecessary motion on site.
\end{abstract}

(C) 2018 The Authors. Published by Diamond Congress Ltd., Budapest University of Technology and Economics Peer-review under responsibility of the scientific committee of the Creative Construction Conference 2018.

Keywords: consolidation, construction transportation, just in time logistics, logistics efficiency, urban construction projects.

\section{Introduction}

In the Netherlands construction activities are changing from development projects to construction and reconstruction projects in cities. About half of the building activities already take place in cities. These construction activities are causing safety and environmental problems, especially when taking the environmental goals of the local authorities into account. Companies that are operating in the construction chains need to contribute to the reduction of these safety and environmental issues, for instance through CO2 reductions. These companies encounter various problems in the way construction chains operate. Suppliers are faced with unpredictability in the supply because of a lack of detail in planning. Because of the frequent last minute planning, adjusting production and stock levels to the provided demand of goods is difficult. The biggest problem for the carriers is the low utilization rate of the vehicles. This is mostly caused by last minute or dedicated supplies to various construction sites in cities, and notably in city centres. Decoupling the delivery process by means of a construction consolidation Construction Consolidation Centre (CCC) is seen by firms, clients and governments as a potentially liable solution to organize construction chains within cities in a more effective, efficient and sustainable way. Aligning comprehensive logistics management is part of supply chain integration strategies [1]. 


\subsection{Relevance and potential of construction transport}

Last few years particularly cities have restrained the entering of polluting vehicles and improving the inner-city climate and air quality in general. Particularly construction transport is relevant to this aim while typically 30 to $40 \%$ of all transport is related to construction. This represents some $40 \%$ of vehicle emissions and road congestions. On the other hand studies on load factors indicate a need to act, while these tend to remain structurally under $50 \%$, in few cases down to 15\%, and far lagging behind other sectors of transport [2]. In the UK and notably London local government and the industry have shifted to action some years ago with demonstrable results.

The London Construction Consolidation Centre (LCCC) claims that the number of construction vehicles to the sites is reduced 68\% [3]. Also LCCC claims that supplier journey time (including loading / unloading time) is reduced two hours [4]. LCCC claims that the delivery performance of goods delivered the first time right is $97 \%$ and that there is an availability of goods of $100 \%$ within 24 hours [5]. LCCC claims that a reduction of materials waste is generated of up to $15 \%$ by reduced damages, less shrinkage and less theft. LCC claims that there is an increase in productivity of the labour force by up to 30 minutes per worker per day [6]. Also improvements of site safety through reduction of materials and packaging on site are reported [7]. To conclude LCCC claims that a reduction of $\mathrm{CO} 2$ emissions, as a direct result of the reduction in vehicles, of about $75 \%$ [8].

\section{Background and method}

This paper reports an ongoing research project in the Netherlands aimed at the advancement of innovative logistical solutions and demonstrating the effects in construction practice. The first year of the project four projects have been observed in close collaboration between firms involved, researchers and students. In the projects novel kinds of solutions have been applied and tested, and the effects have been measured via a set of Key Performance Indicators (KPIs). The research project is both aimed at gaining academic insights and advancing logistic in construction solutions such the use of Construction Consolidation Centres (CCC) in the Netherlands, and thus increasing the efficiency of construction as well as reducing the negative effects of construction transport for society.

Based on projects studied in London, discussions and group sessions that were held and earlier research a basic construction supply chain in the Netherlands, using a CCC is set up. Within this supply chain, the Logistics Service Provider is seen as a Cross Chain Control Centre (4C). The description of these solutions applied and the effects envisaged has been based on the GreenSCOR model [9].

\subsection{Case selection}

To increase our understanding and also uncover areas for further application and research, multiple cases were analysed to explore differences and conformities within and between the four cases (Table 1). We were able to participate in four projects. The projects differ in type, size and location. This has enabled to focus on the differences and conformities how logistics solutions were implemented. The differences give insight how project characteristics affect the dimensions of logistics and the effects of the measures taken.

Table 1: Project cases

\begin{tabular}{|c|c|c|c|c|}
\hline & Project A & Project B & Project C & Project D \\
\hline Type of project & $\begin{array}{l}\text { Newly built housing } \\
\text { blocks incl commercial } \\
\text { spaces and parking } \\
\text { basement }\end{array}$ & $\begin{array}{l}\text { Newly built hotel, } \\
\text { incl parking } \\
\text { basement }\end{array}$ & $\begin{array}{l}\text { Newly built multifunctional } \\
\text { expansion of shopping centre, } \\
\text { incl. hotel and apartments, and } \\
\text { parking basement }\end{array}$ & $\begin{array}{l}\text { Internal refurbishment of } \\
\text { office buildings of a } \\
\text { larger trade centre incl. } \\
\text { the entrance of the centre }\end{array}$ \\
\hline Location & Nearby city centre & $\begin{array}{l}\text { Urban area close to } \\
\text { motorway }\end{array}$ & In city centre & In city centre \\
\hline Duration of the project & 2014-2016 & 2013-2015 & 2013-2019 & 2014 \\
\hline Size of the building & $\begin{array}{l}255 \text { small apartments, } \\
1,500 \mathrm{~m} 2 \text { commercial } \\
\text { space, parking basement }\end{array}$ & $\begin{array}{l}\text { 18,500 m2 hotel, } \\
4,000 \mathrm{~m} 2 \text { parking } \\
\text { for } 136 \text { spaces }\end{array}$ & $\begin{array}{l}35,000 \mathrm{~m} 2 \text { shopping, } 5 \text { level } \\
\text { parking basement for } 1,300 \\
\text { spaces }\end{array}$ & $65,000 \mathrm{~m} 2$ \\
\hline
\end{tabular}




\subsection{Data collection and analysis}

The researchers are present as observers in the project team. During construction the Logistics Service Provider coordinates the logistics activities based on the agreements that were set up during the purchasing processes with suppliers and subcontractors. During construction the main constructor sets up a six week planning. This planning is shared with the Logistics Service Provider in the CCC so they can call off goods at the suppliers.

Next to the above mentioned planning a more detailed, weekly planning is set up. This planning gives insight into the day-to-day operation. Also this planning is shared with the Logistics Service Provider. Based on this planning delivery plans are set up for delivery of the goods to the construction site. Also this planning is leading in the call off at the supplier of goods that need to delivered directly to the construction site. These goods then are directly delivered to the construction site. If there are goods that need to be shipped directly to the construction site, these goods will be called off by the CCC.

Based on the KPI framework the personnel of the firms and the researchers involved have measured and reported the deliveries and the transport movement of the project both taking place at the CCC and on site. These measurements and reports have systematically been put in a database and thus produced the input data to calculate the formulas that represent the KPIs.

\section{Four factors of influence on construction transport}

Construction transport and the effect on process efficiency and the environment can be influenced by different kind of factors. First, transport can be influenced by the way the logistics are managed. More specifically this concerns the extent to which the logistics process can be decoupled and optimised in process parts and load factors of vehicles can be maximised by means of consolidation. Second, the information management of the construction process and the logistics in particular influence the efficiency of construction transport. Third, the packaging and integration of materials into bundles, kits or prefabricated modules that can be shipped and moved in a smart way to the place of installation on site influence the efficiency of transport. Fourth, the extent to which project tendering and purchase contracts consider transport and the effects of it such as CO2 emission as variables or criteria influence the effort contractors, suppliers and logistics service providers put into transport efficiency. At the end of this section these four factors of influence are projected on the four cases, including the logistics measures that were taken in the four projects (Table 2).

\subsection{Logistics management; decoupling and consolidation}

Decoupling the construction chain can be done by using CCCs. The CCC functions as a decoupling point between supplier and construction site. These centres functions as hubs in a few cases already used in construction as a temporary storage at or near the construction site. The CCC then functions as a decoupling point at which supplies to the CCC are controlled in a 'push' way, while goods to the construction site from the CCC are supplied based on the project planning, based on the real and actual need and so controlled in a 'pull' way. There is also a possibility that goods are shipped from the CCC, where the CCC is used as a crossdock. By organizing the supply in this way the supplies are more time-independent than deliveries that are directly shipped to the construction site traditionally (Figure 1).

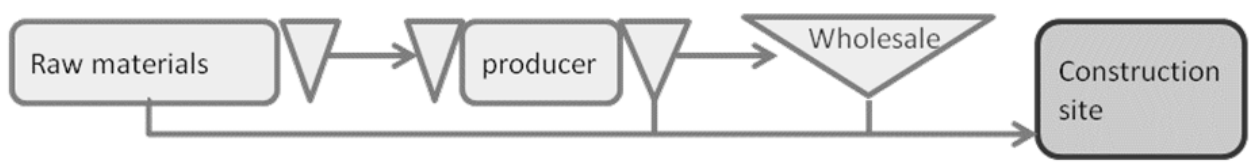

Figure 1: Traditional supply process to a construction site

Materials are not just transported in a JIT manner through the CCC to one site. If required the CCC can be bypassed by supplying goods directly to the construction site, for instance in the case of liquid concrete, full truckloads of heavy material, or supplies that require direct handling on site. Besides multiple sites can be serviced by the same CCC. A CCC can also handle return flows from the construction site including recycling of debris, packaging and equipment (Figure 2). 


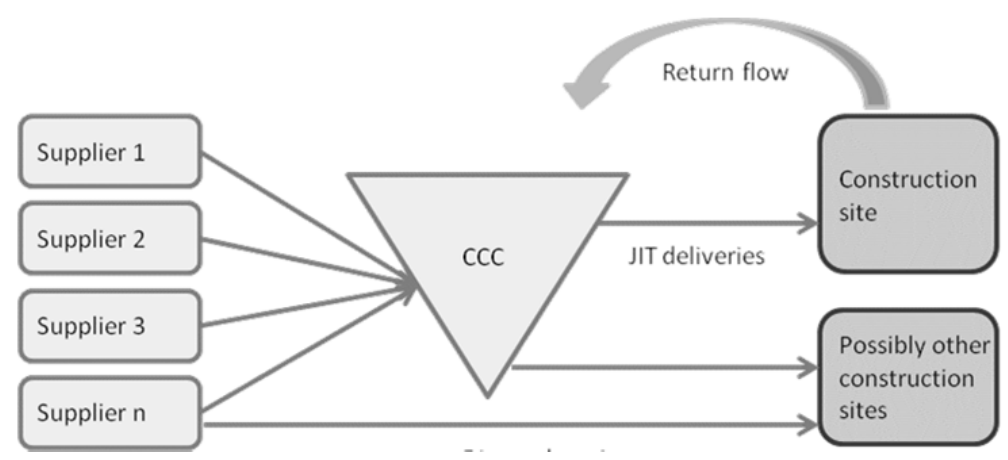

Figure 2: Supply process using a CCC

\subsection{Information management; integrated planning and delivery}

The planning of the delivery to the construction site is done by the Logistics Service Provider in collaboration with the contractor and subcontractors. Also the suppliers are active in planning the deliveries, particularly the (time)critical products and the direct deliveries. The overall planning is finalised and controlled by the main contractor at the construction site.

The resources needed at the construction site are called off at the CCC by the responsible person at the construction site through the Warehouse Management Systems (WMS) functioning at the CCC. This request for resources is at minimum one day before the goods are needed at the construction site. The goods can be picked based on this signal and be transported in consolidated shipments to the construction site controlled by the connected Transport Management Systems (TMS).

The balancing of supply chain resources with supply chain requirements is done by the site manager. Orders that are placed come from the project planning. The information in an order generally contains an article code and name, construction part, the planning, location on site. To organize the information about goods to the construction site in a situation with the CCC a so called 'building ticket' can be used. This ticket is a form with which the supplier presents a supply beforehand. Based on the ticket a logistics coordinator can plan deliveries to the construction site.

\subsection{Prefabrication; off-site construction and kitting}

Particularly at small construction sites there is no space for subcontractors to assemble materials. Therefore it can be a solution that these assembly activities can take place at the CCC. The subcontractor can then assemble goods at the warehouse and have them shipped through regular service to the construction site for installation. This means that goods need to be pulled from stock, taken to the working area where the subcontractor does the assembly work after which the assembled product is put back to stock, meaning new product codes must be generated in the system. Based on the weekly schedule the goods are then shipped to the construction site in a consolidated shipment.

It might happen after assembly modules are becoming hard to handle or kits of material are completely and exactly filled at the supplier's location. In this case a decision can be made that the modules or kits are shipped to the construction site by dedicated deliveries. This means the modules or kits do not pass the CCC and are not put in stock to be called off from there.

This particularly concerns engineered modules, large customized subassemblies, large bulky materials or complete materials packs to finish an entire room in the building for instance. These deliveries are put on site directly and are usually too unpractical to be handled at the CCC. The goods may travel quite a distance from various places. The planning and the time of arrival of those transports needs to be accurate, planned well ahead, to avoid long waiting times once arriving to the site. Vehicle marshalling and control towering are the means to achieve this in particular. If needed the transports are held outside city limits before being called into the city to the site. 


\subsection{Procurement; MEAT tender and strategic purchasing}

Local government have installed restrictions to enter cities and want to keep vehicles out. Also clients who care about sustainability tender via innovative routes and include and reward CO2 reduction as a MEAT criterion (Most Economically Advantageous Tender) in contracts and contractors need to comply to these requirements in their bids in order to win it. This often includes reduction of hindrance for traffic and keeping driving lanes open around and to construction sites. Local governments reward transport and deliveries outside rush hours and even stimulate nightly transport.

In turn some contractors stress the importance and stimulate their suppliers and transport firms to achieve logistics efficiencies. Few studies on supply chain costs rate logistics costs at 10 to $20 \%$ of sales prices (https://www.instituteforsupplymanagement.org/). However adversarial procurement by clients tends to lead to adversarial purchasing of subs and suppliers. In turn subs have generally included logistics costs in their prices and contractors have often bargained a good purchase price from suppliers before the discussion about logistics costs would normally start in projects. Therefore contractors shift to strategic and long-term kinds of purchasing and collaboratively with subs and suppliers drive down logistics costs structurally.

Table 2: Logistics measures taken in projects

\begin{tabular}{|c|c|c|c|c|}
\hline & Project A & Project B & Project C & Project D \\
\hline Logistics management & $\begin{array}{l}\text { CCC, Buffering, } \\
\text { consolidation, waste } \\
\text { disposal in same loop, } \\
\text { group transport of } \\
\text { workers and equipment }\end{array}$ & $\begin{array}{l}\text { Buffer location for } \\
\text { trucks close to site }\end{array}$ & $\begin{array}{l}\text { CCC, Buffering, } \\
\text { consolidation, waste } \\
\text { disposal in same loop }\end{array}$ & $\begin{array}{l}\text { CCC, Buffering, } \\
\text { consolidation, waste } \\
\text { disposal in same loop, } \\
\text { public/ group transport } \\
\text { of workers and } \\
\text { equipment }\end{array}$ \\
\hline Information management & $\begin{array}{l}\text { Input from BIM, Solibri } \\
\text { into TMS }\end{array}$ & $\begin{array}{l}\text { Online transport tickets } \\
\text { per delivery, online } \\
\text { WMS and TMS }\end{array}$ & $\begin{array}{l}\text { Online transport tickets } \\
\text { per delivery, online } \\
\text { WMS and TMS }\end{array}$ & $\begin{array}{l}\text { Printed transport tickets } \\
\text { per delivery }\end{array}$ \\
\hline Prefabrication, kitting & $\begin{array}{l}\text { Prefabricating e.g. of } \\
\text { rebar modules at CCC, } \\
\text { kitting of daily batches }\end{array}$ & $\begin{array}{l}\text { Kitting of daily batches } \\
\text { at CCC, all fit-out } \\
\text { material per room per kit }\end{array}$ & $\begin{array}{l}\text { Kitting of daily batches } \\
\text { at CCC }\end{array}$ & $\begin{array}{l}\text { Kitting of daily batches } \\
\text { at CCC }\end{array}$ \\
\hline Procurement, purchasing & $\mathrm{n} / \mathrm{a}$ & $\begin{array}{l}\text { LEED tender with } \\
\text { implications for reduced } \\
\text { vehicle movements }\end{array}$ & $\mathrm{n} / \mathrm{a}$ & $\begin{array}{l}\mathrm{CO} 2 \text { criteria in MEAT } \\
\text { tender aimed at reduced } \\
\text { vehicle movements }\end{array}$ \\
\hline
\end{tabular}

\section{Empirical findings and results}

In this section we explore the differences within and between the four projects using the KPI framework as a guide (Table 3). The findings are partly qualitative and partly quantitative. The description of the findings partly focus on elements that are not present in the framework or that might deepen our understanding on how to operationalise its dimensions. Within the ongoing research reported the KPI framework is subject of continual development, which is also true for the projects and solutions applied. The fieldwork done at the projects is therefore input for further advancement of the logistics management of the projects (Table 4).

\subsection{KPI framework}

The KPI framework presented below is based on the GreenSCOR model [9] adapted to a construction context. The indicators and measurements are also based on the construction practices in the UK and the Netherlands applying advanced logistics solutions. The KPIs are formulated to monitor the construction and logistics processes, and also to gain data to measure the effect of logistics measures taken, such as the use of a CCC. 
Table 3: KPI framework

\begin{tabular}{|c|c|c|}
\hline & Indicators & Measurement \\
\hline Reliability & $\begin{array}{l}\text { Percentage deliveries on time, and } \\
\text { complying to quality and requirements }\end{array}$ & $\begin{array}{l}\text { Amount of deliveries on time and complying to requirements, and } \\
\text { reason why not if not, and consequences/costs to fix }\end{array}$ \\
\hline Responsiveness & $\begin{array}{l}\text { Offloading and waiting times of deliveries } \\
\text { on site }\end{array}$ & $\begin{array}{l}\text { Waiting time of trucks before being offloaded on site, and waiting time } \\
\text { of personnel and equipment on site before being able to offload }\end{array}$ \\
\hline Agility & $\begin{array}{l}\text { Lead times of orders delivered from CCC to } \\
\text { site, and from suppliers to CCC }\end{array}$ & $\begin{array}{l}\text { Time needed to place and process an order from the CCC and } \\
\text { suppliers, and being delivered to the site }\end{array}$ \\
\hline Costs & $\begin{array}{l}\text { Productivity gains on site, purchase price } \\
\text { reductions, transport costs reductions }\end{array}$ & $\begin{array}{l}\text { Less time wasted by workers on site, eliminating logistics cost } \\
\text { elements by suppliers, reduction of travel distance and time or bundling } \\
\text { of deliveries of suppliers }\end{array}$ \\
\hline Assets & $\begin{array}{l}\text { transport efficiency, load factor of trucks, } \\
\text { consolidation factor of CCC, days of stock at } \\
\text { CCC }\end{array}$ & $\begin{array}{l}\text { Transport volume and weight of trucks to and from site; Amount of } \\
\text { trucks from supplier to CCC vs CCC to site }\end{array}$ \\
\hline Environment & $\begin{array}{l}\text { environmental impact, } \mathrm{CO} 2 \text { emission, waste } \\
\text { reduction, noise, hindrance, health, safety }\end{array}$ & $\begin{array}{l}\text { Amount of fuel use, amounts of waste, packaging, debris, numbers of } \\
\text { complaints, incidents, accidents, traffic jams caused }\end{array}$ \\
\hline
\end{tabular}

\subsection{Project $A$}

In this specific case the site is located at a canal and thus the potential of water transport had been studied and the consequences for costs, emission and planning. It remained unclear what exactly the extra costs and time use would be of the transfer to water transport. CO2 would reduce but other emissions such as NOx and SO2 would increase because of the fuel used for the boats. Also the materials need to be packed in specific ways to be able to be transported by boat. On site specific equipment had been tried such as floor extensions to be able to easily pull in material and kits from the building elevator onto the floor.

For the information management and support of optimised transport all data needed from suppliers were analysed and validated in the BIM model of the project. This data contained all product specific details, location, time and transport and handling equipment. This data was connected to the planning software on site and the TMS of the transport firm. The data were printed on 'building tickets' that functioned as an order form from site to the CCC and suppliers, which could contain QR codes or tagging via RFID would be possible in later stage.

\subsection{Project $B$}

In this case, the building of an new hotel, the logistics management had been concentrating on the tower crane efficiency; the materials supply onto floors and carrying off debris from the floors. The aim was to balance and increase the efficiency of the arrival of deliveries on site, subsequent offloading by the crane, storage on site, the crane taking the materials up to the floor, and installing the materials on the floor. This project did not work with a CCC but was supplied directly from the suppliers plants, particularly concrete, rebar and formwork. This was followed by the HVAC firm whose factory functioned as a place where the materials kits of all materials per hotel room were bundled including all ductwork and finishing.

The site used an online TMS and 'building tickets' including registration of all arriving deliveries from the suppliers and the HVAC firm's location. This led to a continuous information flow to be able to manage the deliveries more accurately, and plan the tower crane's capacity more efficiently. This also reduced the amount of waiting vehicles and traffic jams around the site. As a safeguard, once trucks approached the site they were able to use a buffering location if needed, in case they would arrive untimely.

\subsection{Project $C$}

This case is logistically comparable to case B although in this case a CCC was used. Since the project is that large there were dedicated logistics personnel on site as well as at the hub. This personnel was equipped with portable computers with applications to access the online TMS and WMS platform, also including the planning of all cranes, and all entrance and storage locations on site. These integrated systems enabled suppliers and transport firms driving up and down from the site to the CCC to deliver materials and carry off debris in a highly accurate manner. However 
the size of the project and the amount of suppliers and subcontractors caused quite a bit of improvisation and deliveries that evaded the online system and still caused traffic jams and inefficiencies on the site and around.

Since the project site is located in the very city centre next to the central railway station all disruptions caused quite a bit of congestions. The city is keen to prevent this and reduce emissions caused by vehicles. As an extra measure most of the deliveries were planned outside rush hours and particularly in the early mornings and in the evenings. As a consequence these deliveries took less time and produced less emission.

\subsection{Project $D$}

This project had been contracted as a MEAT tender (Most Economically Advantageous Tender) applying CO2 emissions of supplies, travel of personnel and carrying off debris as criteria to the bids of contractors and rewarded this in the appraisal of the bids, besides the price, planning and quality. The winning bid managed to offer the lowest $\mathrm{CO} 2$ emission. In the tender a traditional calculation of the emission was given of $42,000 \mathrm{~kg}$ the project would produce when executed applying traditional logistics management. The winning bid offered to do the project applying a CCC for all deliveries and carrying off debris, and group and public transport of personnel, resulting in $17,000 \mathrm{~kg}$ emission i.e. a reduction of $60 \%$. Based on the registration of all vehicle movements the real emission of the project appeared to be $22,500 \mathrm{~kg}$ i.e. a reduction of $46 \%$. This was caused by displacement of the CCC on further distance from the site, and lower load factors than offered in the bid.

Table 4: Empirical findings and results

\begin{tabular}{|c|c|c|c|c|}
\hline & Project A & Project B & Project C & Project D \\
\hline Reliability & $\begin{array}{l}\text { Most deliveries arriving on } \\
\text { time from CCC to site }\end{array}$ & $\begin{array}{l}\text { More than traditional } \\
\text { deliveries arriving on time } \\
\text { from suppliers to site }\end{array}$ & $\begin{array}{l}\text { With online transport ticket } \\
\text { deliveries within } 10 \text { min } \\
\text { time frame; without ticket } \\
\text { 1:30 hrs }\end{array}$ & $\begin{array}{l}\text { Most deliveries arriving on } \\
\text { time from CCC to site }\end{array}$ \\
\hline Responsiveness & $\begin{array}{l}\text { TMS gives insight in } \\
\text { deliveries, taking less time } \\
\text { for site personnel to } \\
\text { offload }\end{array}$ & $\begin{array}{l}\text { Offloading of all deliveries } \\
\text { strictly planned via online } \\
\text { tickets and followed up by } \\
\text { personnel }\end{array}$ & $\begin{array}{l}\text { Offloading of all deliveries } \\
\text { strictly planned via online } \\
\text { tickets and followed up by } \\
\text { personnel }\end{array}$ & $\begin{array}{l}\text { In most cases site } \\
\text { personnel is aware of } \\
\text { deliveries planned and take } \\
\text { less time for offloading }\end{array}$ \\
\hline Agility & $\begin{array}{l}\text { Orders from site to CCC } \\
\text { come few days to week in } \\
\text { advance based on online } \\
\text { planning }\end{array}$ & $\begin{array}{l}\text { Online WMS allows orders } \\
\text { from site to CCC till two } \\
\text { days in advance }\end{array}$ & $\begin{array}{l}\text { Online WMS allows orders } \\
\text { from site to CCC till two } \\
\text { days in advance }\end{array}$ & $\begin{array}{l}\text { Local WMS at CCC allow } \\
\text { orders from site few days } \\
\text { in advance }\end{array}$ \\
\hline Costs & $\begin{array}{l}\text { Prefabrication of rebar and } \\
\text { kitting resulted in faster } \\
\text { working, less time wasted } \\
\text { on site }\end{array}$ & $\begin{array}{l}\text { Bundled deliveries, kitting } \\
\text { resulted in faster working, } \\
\text { less time wasted on site }\end{array}$ & $\begin{array}{l}\text { Bundled deliveries, kitting } \\
\text { resulted in faster working, } \\
\text { less time wasted on site }\end{array}$ & $\begin{array}{l}\text { Lower bid caused by lower } \\
\text { transport costs and higher } \\
\text { productivity based on } \\
\text { firms' previous experiences }\end{array}$ \\
\hline Assets & $\begin{array}{l}\text { Less vehicles to and from } \\
\text { site, than traditional, } \\
\text { bundling, debris in same } \\
\text { loop }\end{array}$ & $\begin{array}{l}\text { Less vehicles to and from } \\
\text { site, than traditional, } \\
\text { bundling, debris in same loop }\end{array}$ & $\begin{array}{l}\text { Consolidation of deliveries } \\
\text { at CCC leading up to } 60 \% \\
\text { less vehicles from CCC to } \\
\text { site }\end{array}$ & $\begin{array}{l}\text { Consolidation of deliveries } \\
\text { at CCC leading up to } 70 \% \\
\text { less vehicles to site and no } \\
\text { return }\end{array}$ \\
\hline Environment & $\begin{array}{l}\text { Less emission due to less } \\
\text { vehicles, less annoyance in } \\
\text { neighbourhood of workers } \\
\text { not taking parking space }\end{array}$ & $\begin{array}{l}\text { Less emission due to less } \\
\text { vehicles, less hindrance } \\
\text { around site due to stricter } \\
\text { planned deliveries and faster } \\
\text { offloading }\end{array}$ & $\begin{array}{l}\text { Deliveries avoiding rush } \\
\text { hours took } 25 \% \text { less travel } \\
\text { time, } 11 \% \text { less emission as } \\
\text { a result }\end{array}$ & $\begin{array}{l}\text { Reduced } \mathrm{CO} 2 \text { emission } \\
22,500 \mathrm{~kg} \text { during project } \\
\text { i.e. } 46 \% \text { less than } \\
\text { traditional as based on } \\
\text { contract }\end{array}$ \\
\hline
\end{tabular}

\section{Conclusions}

In this paper we observed four project cases applying advanced logistics solutions. The effects of these applications were assessed based on the KPI framework which was constructed for the research project reported. In the six dimensions of the framework all four projects performed better logistically than what the projects would do traditionally. This implied improved transport efficiency and reduced environmental impact of the transport. The observations supported the applicability and usefulness of the framework and the benefits of improved transport and logistics management in construction. 
The KPI framework appeared to be quite useful in describing the level of performance of the projects and the four factors of influence on the construction transport of the projects. Although the scope of the performance and the factors covered a wider range of issues than the framework could assess directly, the framework was able to accommodate also those influences on the projects and the construction transport.

The application of a CCC and other efforts to decouple and consolidate construction transport have been found to play a key role in the logistics solutions and to achieve the effects reported. Second, applications of information management, notably Warehouse Management Systems (WMS) and Transport Management Systems (TMS), are playing an increasingly important role to coordinate the stocks at the CCC and ensure accurate deliveries from the CCC to site. The coordination is starting to extend to the design phase via BIM applications such as Solibri in order to determine daily materials packages to construction sites efficiently. Modularisation and kitting of material packages is a way forward in which much is to be gained in terms of production. Fourth, tendering and purchasing based on MEAT criteria rewarding CO2 reductions by clients and governments, and also construction firms towards suppliers and transport firms will likely encourage further efforts to improve transport efficiencies and reduce the environmental impact of construction transport.

Notwithstanding the benefits and potential, the scope of these improvements focus mainly on the 'last mile', notably the transport from the CCC to the site. In most cases though the deliveries from suppliers to the CCC are not acted upon, although there is an improvement potential here too. Further, and this goes for the application of the KPI framework as for ICT instruments mentioned, firms and individuals along the supply chain must be aware and systematically use and keep up those tools to be effective and cause the desired impact.

\section{Acknowledgements}

This paper has been partly based on an applied research project entitled '4C for Construction Logistics' in the Netherlands, which has been largely funded by Top Consortia for Knowledge and Innovation TKI and the Netherlands Organisation for Scientific Research NWO. We are grateful for the use of the results from the cooperation with the project consortium partners, and the support received from the funding.

\section{References}

[1] Vrijhoef, R. (2011). Supply chain integration in the building industry: The emergence of integrated and repetitive strategies in a fragmented and project-driven industry. PhD Thesis. Ios Press, Amsterdam.

[2] Sullivan, Barthorpe and Robbins (2010). Managing Construction Logistics. Wiley-Blackwell, Chichester.

[3] Brett, P. (2007). Construction Consolidation Centres; An Assessment of the Potential for London wide use. Project Ref: 17321/004, May, 2007.

[4] MVA (2006). Overview on Consolidation Centres, 20 October 2006, MVA Consultancy.

[5] Constructing Excellence (2007). London Construction Consolidation Centre. Interim Report - May 2007. Transport for London. In partnership with Bovis Lend Lease, Constructing Excellence, Stanhope.

[6] Transport and Travel (2010). Freight Consolidation Centre Study. Main Report. Prepared for Department for Transport. Transport and travel research Ltd. Version 1.0 14th July 2010.

[7] Department for Transport (2007). London Construction Consolidation Centre. Freight Best Practice. Department for Transport, October 2007.

[8] Transport for London (2008). London Construction Consolidation Centre. Final Report - April 2008 rev October 2008. Transport for London, In partnership with Bovis Lend Lease, Constructing Excellence, Stanhope, Wilson James, University of Westminster

[9] SCC (2010) SCOR Supply Chain Operations Reference (SCOR®) model Overview - Version 10.0. Supply Chain Council, Cypress, TX USA, supply-chain.org. 